\title{
NANO SCALE METHODS FOR WATER POLLUTION MONITORING
}

\author{
Eva Trumsina, Silvia Kukle, Gunta Zommere \\ Riga Technical University, Institute of Textile Materials Technologies and Design \\ 14/24 Azenes St, Riga, LV 1048, Latvia \\ Ph.: +371 67089816, fax: +371 67089160, e-mail: eva_trumsina@inbox.lv
}

\begin{abstract}
The article deals with issues related to the textiles coated with metal nanoparticles and detection of the concentrations of released particles in water. The main risks associated with the use of metal covered textiles are detaching of metal nanoparticles from the material during use and care and thus polluting the environment, or inhaled to get in a human or animal body. Nanoparticles can be detached from the textile during washing also, thus polluting the water body and making detriment to the living beings in them. This article aims to look at equipment for nanoparticle size and concentration detection in liquids. Described the world's most popular methods (Microscopy techniques, Photon Correlation Spectroscopy, Nanoparticle Tracking Analysis) and compared to new, alternative method - Gas Discharge Visualization (GDV) electrography. Within the framework of the article analyzed the advantages and disadvantages of each method and estimated the perspective of GDV electrography for detection of metal nanoparticles in water.
\end{abstract}

Keywords: GDV electrography, metal covered textile, nanoparticles, testing methods.

\section{Introduction}

The article deals with issues related to the textile coated with metal nanoparticles, the persistence of the metal coverings and detection of the concentrations of released particles in water. The main risks associated with the use of metal covered textiles are detaching of metal nanoparticles from the material during use and care. Friction resulting nanoparticles can be detached from the product and thus end up in the air, resulting in polluting of the environment, or inhaled to get in a human or animal body. Nanoparticles can be detached from the textile during washing also, thus polluting the water body and to the detriment of the living beings in them.

Quantitative assessment of the impact of nanoparticles and an adequate characterization is still a serious problem for scientists, industrial hygienists and toxicologists. Nanoparticle detection methods and their specific parameters measuring is necessary for two reasons: first, to detect nanoparticles in environments in which people and ecosystems are exposed to their influences such as water, air, soil, nanocomposites and consumer products. The second reason is the need to measure the physical and chemical properties of nanoparticles in these environments. Nanoparticles dimensions are outside the visible light diffraction limit, so that in the optical microscope they are not visible, it creates a need for highly sensitive testing method.

The most common nanoparticle detection equipment is allocated according to environment in which the particles are disposed - fluid, air or solids. Nanoparticle detection methods and equipment can be divided also according to the parameters which they calculate - the mass concentration, particle number (numerical concentration), surface specific (surface concentration) or granulometric structure. In literature is found the following breakdown devices attached to a computer (on-line) and equipment that are not connected to the computer (off-line).

The article deals with certain equipment and methods for detecting of nanoparticles in fluids, as well as analysis of relatively new method (Gas Discharge Visualization (GDV) electrography) possible use for metal nanoparticles level monitoring in water. 


\section{Materials and methods}

Quantitative determination of nanoparticles is problematic, because virtually in every environment is the presence of natural origin nanoparticles. Of the total suspension, which is a complex mixture of different composition and granulometry nanoparticles, must isolate interested objects. So the first must find all the nanoparticle composition, to select necessary components and determine their parameters.

Analised devices vary with the required sample number for measurements, preparation techniques and the resulting parameter range. For several equipment necessary special preparation of the sample, but can meet such devices which permit the measurement of raw substance. The required pre-treatment is problematic because the sample may react or decompose during the preparation. The required quantity of material for testing may limit the choice of equipment, because, according to the apparatus, the sample requires up to $300 \mu 1$. Some equipment needs of additional measurements in order to calculate any of the indicators. Most of the equipment cannot distinguish agglomerates from individual nanoparticles, which limits their use, because the toxicity of nanoparticles depends on their size - the size reduction increases toxicity. So toxicity of nanoparticles agglomerate will be higher than the same size bulk substance toxicity. If device nanoparticle agglomerates considered as a single element, the wrong suspension toxicity is calculated.

This section deals with three main methods for the analysis of nanoparticles in liquids Microscopy techniques, Photon Correlation Spectroscopy and Nanoparticle Tracking Analysis. The article gives the general characteristics of the equipment. Instrument sensitivity, use and accuracy can vary depending on the manufacturer.

Microscopy methods. In Transmission Electron Microscopy (TEM) is used an electron beam, which by interacting with the sample, form an image on photographic plate or in a specialized camera. The sample must be able to withstand the electron beam and the high vacuum chamber, where it is placed. The sample must be made in the form of thin film, which in turn can cause problems. The method is also time consuming and therefore increase the costs [1].

In High-Resolution Transmission Electron Microscopy (HRTEM) can observe the sample crystallographic structure in the atomic level. HRTEM maximum resolution is $0.08 \mathrm{~nm}$. Method is used in semiconductor and metal properties nano scale study. In High-Resolution Transmission Electron Microscopy is used phase contrast or high resolution imaging technique. Phase contrast imaging analyzes through the sample atoms going electron beam diffraction contrast in comparison with the transmitted beam contrast. HRTEM use limits complexity of image interpretation, which includes a variety of mathematical calculations, such as a determination of microscope lens aperture and aberrations caused image distortions [1].

Environmental Transmission Electron Microscopy (ETEM) compared with conventional TEM is a significant advantage - the sample must not be placed in a vacuum chamber, the process may be carried out in situ [1].

In the Scanning Electron Microscopy (SEM) is also used electron beam, only in this case the sample surface is scanned, and the image forms the back scattered electrons. SEM disadvantage is that the sample is placed in a vacuum chamber and surface of the sample must be electro conductive. On the samples with low electrical conductivity is sprayed metal coating, as a result Scanning Electron Microscope application is limited, and sample preparation process is time consuming and expensive [2].

One of the Scanning Electron Microscope modification is Environmental Scanning Electron Microscope (ESEM), which, like a ETEM, suitable for operation in low pressure gaseous environment [2].

Scanning Transmission Electron Microscope (STEM) combines the scanning and transmission electron microscopy features - can be obtained images of the sample surface and the internal structure [2]. 
Atomic Force Microscope (AFM) is a Scanning Probe Microscopy (SPM) type, which uses a mechanical probe to palpate the sample surface. Atomic Force Microscope is one of the most commonly used equipment in nano scale substances measuring and displaying.

Console with nano scale probe moves over the sample surface, vibrations of the console and therefore the sample surface is fixed with the reflected laser beam, which is received in photodiodes matrix. In this way can obtain three-dimensional image. AFM are several test modes - contact mode, non-contact mode, and intermittent contact mode. To see the nanoparticles with the Atomic Force Microscope, they must be dispersed in the air or liquid, and the substrate must be less rough than the particles to be measured. This method is less time-consuming and lower-cost [3].

The benefits of Microscopy methods include the high resolution - up to $1 \mathrm{~nm}$.

The main disadvantages of Microscopy methods in measuring nanoparticles are referred to the complex sample preparation. Another problem is sample selection, because the picture in the microscope is a small fraction of the total sample, therefore difficult to determine whether the findings of the research relate to whole object.

Photon Correlation Spectroscopy. In Photon Correlation Spectroscopy (PCS) analyses from the nanoparticles reflected laser beam created curve. By combining this method with the Brownian motion caused diffusion calculations by Einstein - Stokes equation acquires the average particle size and size distribution in the sample. The sample must be liquid, solution or suspension in a low concentration, otherwise the light scattering is not clear. Measuring equipment is sensitive to impurities, and must be given sample viscosity. Particle size range that can be detected by Photon Correlation Spectroscopy ranges from $1 \mathrm{~nm}$ to $10 \mu \mathrm{m}$ [4].

For application of Photon Correlation Spectroscopy in higher concentrations or opaque samples testing, was created Photon Cross Correlation Spectroscopy (PCCS), which can be applied even in emulsion analysis [5].

Nanoparticle Tracking Analysis. Nanoparticle Tracking Analysis (NTA) provides information on particle size, size distribution and observation of nanoparticles in the sample in real time (Fig.1).

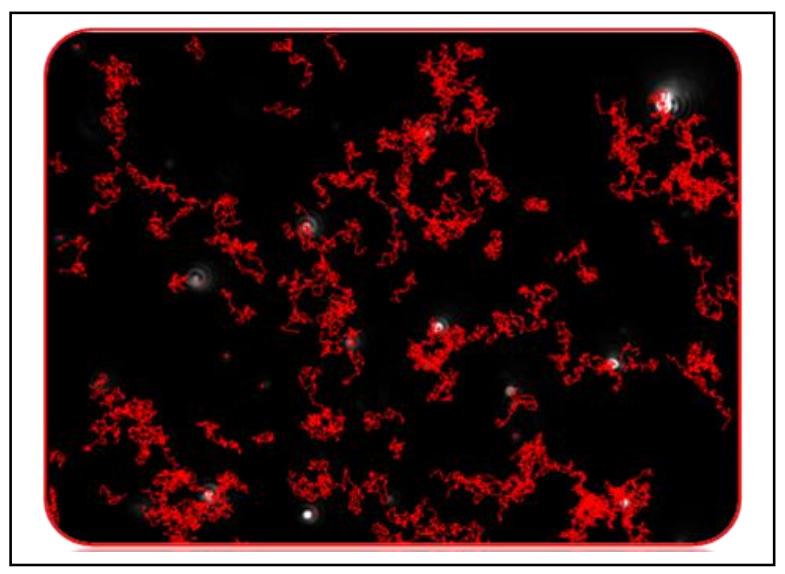

\section{Fig.1. Monitoring of the nanoparticle movements in NTA equipment [6]}

The sample must be a suspension; it is placed on an opaque background and using a laser, observes the movements of nanoparticles in the optical microscope. In the device is also a digital camera to record the movement of particles. By a computer program is created nanoparticle size distribution frequency chart. NTA equipment may be used together with Photon Correlation Spectroscopy, thus increasing the amount and the accuracy of the obtained information [7].

Gas Discharge Visualization Electrography (GDV EG) working principle is based on Kirlian effect. High-frequency high-voltage current produced discharge or radiation around an object (human, animal body parts, plant, inanimate object or liquid) is detected by a digital 
camera in separate shots or video format. The resulting images are analyzed by specialized software. Radiation shape and size reflect the object properties.

GDV camera is the most widely used in medical studies - allergy diagnosis [8], the diagnosis of autism [9], various fluids (for example, blood, energetic preparations, homeopathic preparations) properties determination by influence of different factors [10]. GDV camera is widely used in sports medicine - sportsman's training and health status estimation [11]. GDV equipment may be used in powerful, geo-active places surveys, as well as the impact of such locations exploration [12].

In view of the GDV electrography broad spectrum of use, proposed the task to adapt the method for nano scale metal particles detection in water. In order to clarify the method outlook of reaching the target carried out pilotexperiment with four cotton fabric samples coated with copper particles (size 180-210 nm) layer in a thermal evaporation process. Thermal evaporation process duration - 3 seconds.

Samples washed in cold water by hand for about 5 minutes, in resulting the copper coating diverged from the textile, shown by the water color changes and easily reddish precipitate at the bottom of the container. The sample size - 75x85 mm; washing water for one sample - 60 ml. For comparison used uncontaminated cold water (designation- control). Water stored in enclosed glass container.

Before the GDV electrography session, the container with water is thoroughly shaked to disperse the sludge. Prepared water $(1-2 \mathrm{ml})$ embroiled into a syringe and a syringe fixed on a stand above the GDV camera lens. From one sample get 5 static GDV electrogramms. The experiment is repeated 8 times, resulting in a 40 pictures of the same time interval between electrogramm fixing moments. Time intervals, used in experiment (3, 5 and 7 seconds), and number of images ( 5 electrogramms) is entered into the program "GDV Capture" settings.

GDV electrogramms fixed with gas discharge visualization camera "GDV Camera" using toolkit "GDV Mini-Lab" for liquid analysis. The data recorded in a computer program "GDV Capture" and processed in the program "GDV Scientific Laboratory". The resulting parametric analysis was conducted in "Microsoft Excel" software.

\section{Results and discussion}

A computer program "GDV Scientific Laboratory" calculates 12 parameters for each electrogramm. The most important parameters of the radiation are area, intensity, form coefficient and entropy. This paper presents two leading indicators- the area and intensity; they both describe the object energy potential. Area of GDV electrogramms is number of pixels in the picture or electrogramm, but the intensity is brightness of the picture elements (pixels).

During the analysis of the experiments calculated various statistical indicators - the arithmetic mean, variance, range, standard deviation, average standard error and relative average standard error. The measurements obtained from four samples, pooled into two groups (designation Group 1A and Group 1B) for better obviousness.

Figure 2 represents the water samples mean values at three different electrogramms exposure intervals (3, 5 and 7 seconds). Each of the indicators calculated as the arithmetic mean of 40 values. The relative average standard error don't exceed 3\% limit for anyone of the data packages, so calculus have sufficient reliability.

Figure 2 illustrates the area differences in pixels for the washing water of Group1A samples and fresh water (control), receiving GDV electrogramms with different time intervals between the fixing moments $(3,5$ and 7 seconds). In this case, 3 -second pause between the image fixing moments show the smallest differences between polluted and unpolluted water. 


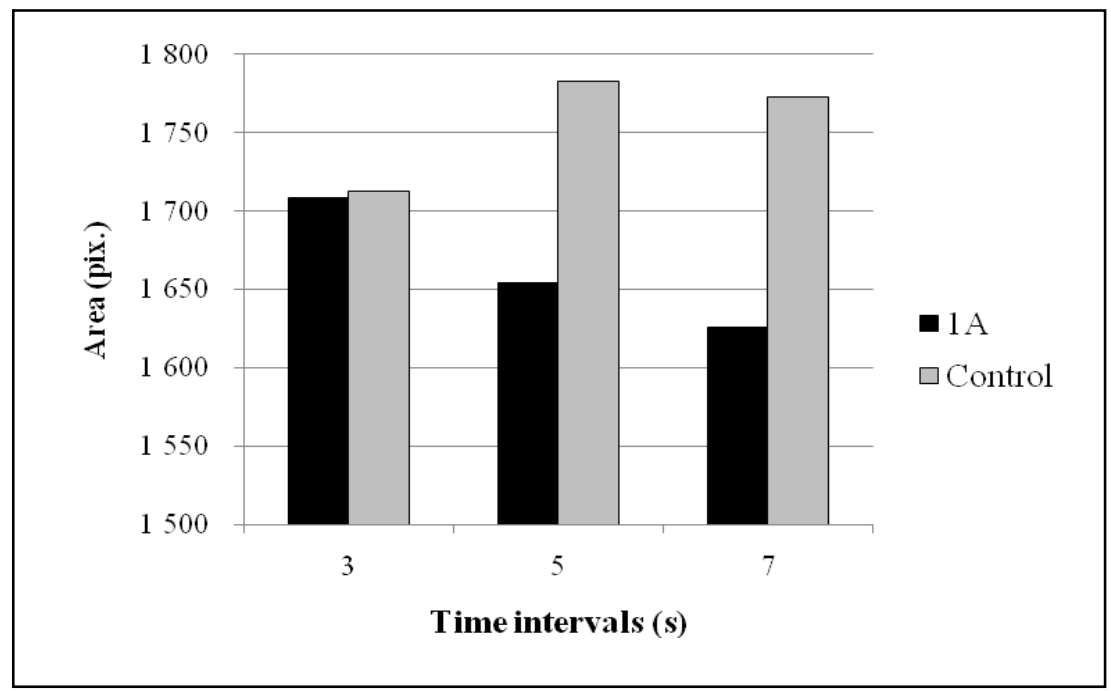

Fig.2. Indicators of area for $1 \mathrm{~A}$ samples washing water and uncontaminated water

As shown in Figure 3, for Group 1B samples all of the time intervals present enough significant differences between polluted and unpolluted water.

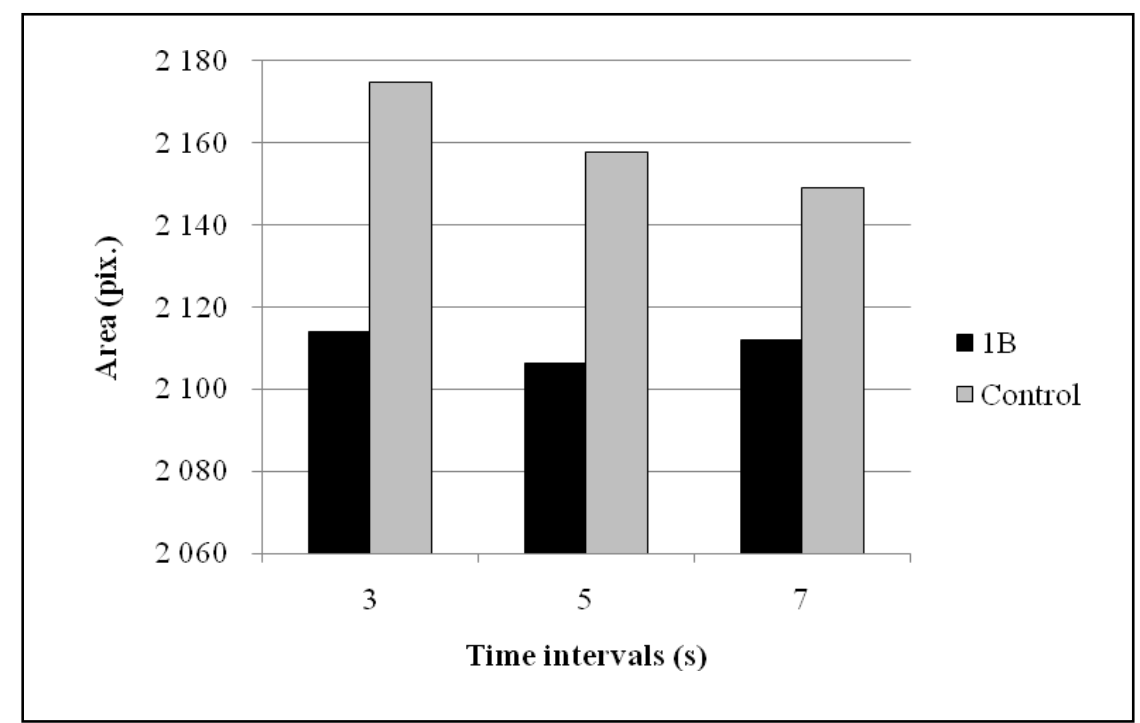

Fig.3. Indicators of area for 1B samples washing water and uncontaminated water

Figure 4 represents the GDV electrogramms intensity results obtained from samples 1A washing water and clean water. In this variant smallest difference between polluted and unpolluted water show electrogramms taken with 7-second intervals.

In Figure 5 represented intensity indices for Group 1B samples washing water and control water radiation, show the smallest difference between electrogramms, taken with 5-second intervals.

Summarizing results of pilotexperiment, it appears that the GDV electrography method show differences between polluted and unpolluted water samples at all measurement points, and unpolluted water radiation area and intensity are higher than the contaminated water. This means that the method is usable for detection of metal nanoparticles pollution in water. However, the results must be stabilized, it can be achieved taking a video file instead of detached electrogramms and analyzing the resulting set of shots. 


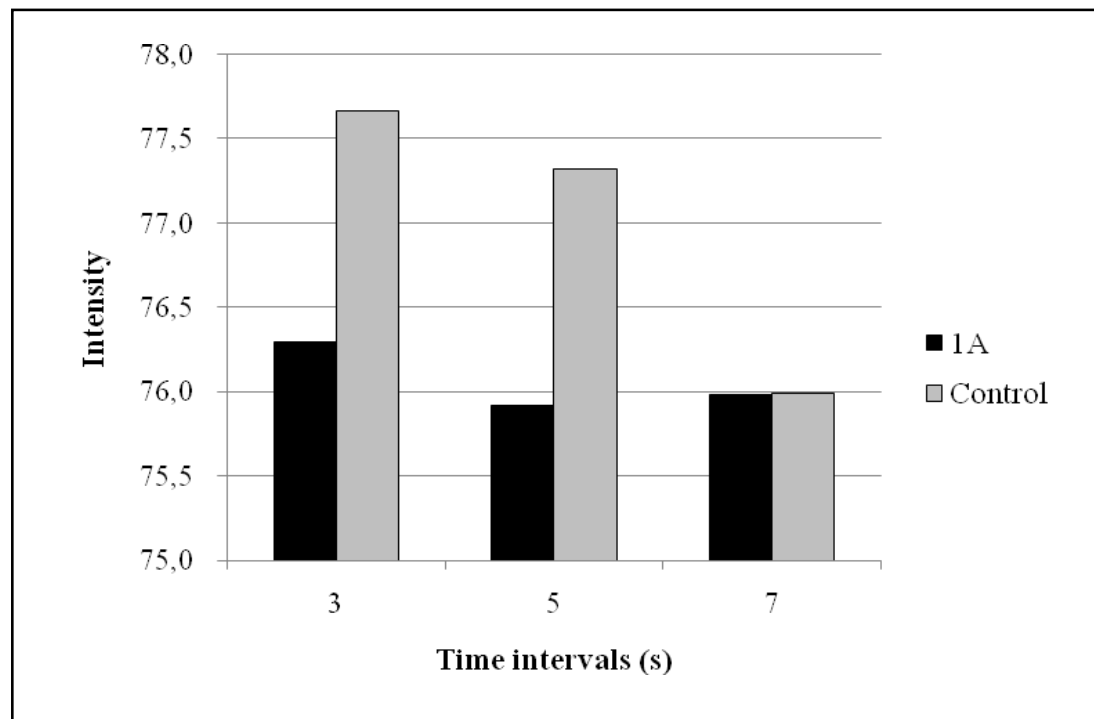

Fig.4. Indicators of intensity for 1A samples washing water and uncontaminated water

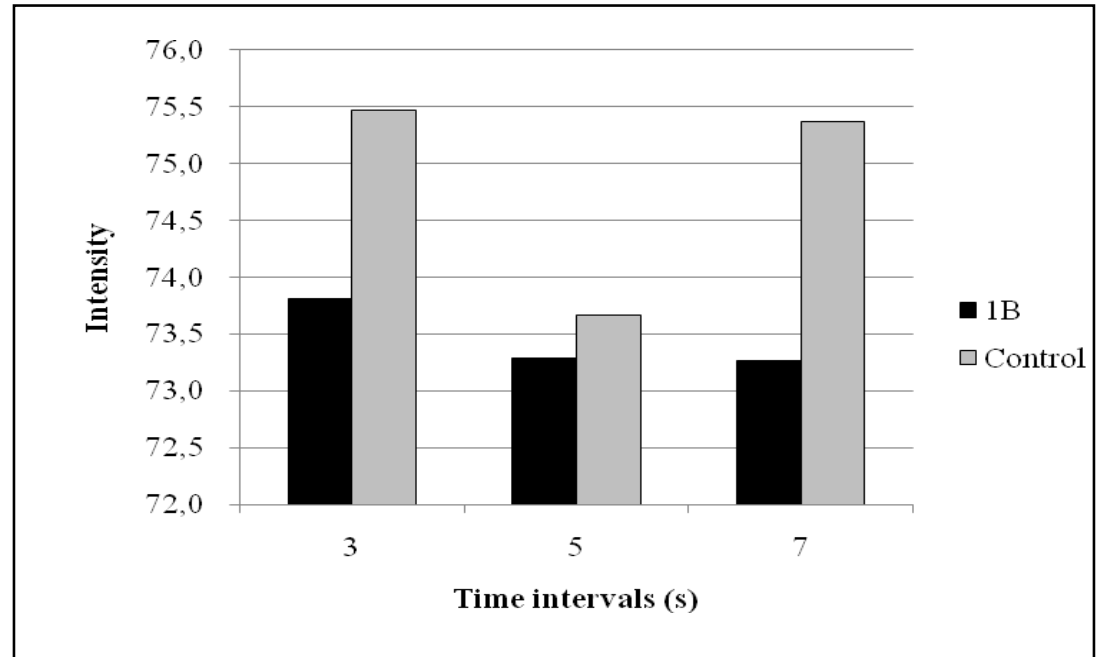

Fig.5. Indicators of intensity for 1B samples washing water and uncontaminated water

\section{Acknowledgment}

This work has been partly supported by the European Social Found within the National Program at Riga Technical University.

\section{Conclusions}

In the paper presented methods for nanoparticle detection in liquids differ with parameters they calculate - Photon Correlation Spectroscopy and Nanoparticle Tracking Analysis estimate particle size and size distribution, with Microscopy techniques can detect particle size and surface properties, while the GDV electrography characterizes energetic characteristics of the liquid's radiation.

Each method has also disadvantages - Photon Correlation Spectroscopy is necessary to know the viscosity of the sample, while Microscopy methods require prior sample preparation, which is expensive and time-consuming process. In addition, all methods have nanoparticle size limits imposed by its ability to capture. Recognition of nanoparticle agglomerates is quite problematic also. Such problems have not GDV electrography, because it analyzes the radiation of fluid, whose properties depend on its composition. Nanoparticle size or the agglomerates does not change capture capabilities of the equipment. However, GDV camera also has drawbacks - it cannot be used in detection of nanoparticles of unknown origin, when is needed to know the chemical composition of particles. Respectively, developing an 
appropriate measurement methodology, GDV camera can be used in detecting a known source of nanoparticles in water.

\section{References}

1. Williams, D.B. Transmission Electron Microscopy. A Textbook for Materials Science. Second Edition. Heidelberg: Springer-Verlag, 2009, p. 757.

2. Reimer, L. Scanning Electron Microscopy. Physics of Image Formation and Microanalysis. Second Edition. Heidelberg: Springer-Verlag, 1998, p. 515.

3. Eaton, P., West, P. Atomic Force Microscopy. Oxford: Oxford University Press, 2010, p. 241.

4. Berne, B.J., Pecora R. Dynamic Light Scattering: with Applications in Chemistry, Biology, Physics. Ontario: General Publishing Company, 2000, p. 371.

5. Photon Cross Correlation Spectroscopy. Sympatec GmbH. System-Partikel-Technik. Available from: http://www.sympatec.com/PCCS/PCCS.html Accessed: 2010-12-29

6. Comparative Technologies. NanoSight. Available from:

http://www.nanosight.com/technology/comparative-technologies Accessed: 2011-01-14

7. Elsersawi, A. World of Nanobioengineering. Potential Big Ideas for the Future. Bloomington: AuthorHouse, 2010. p. 196.

8. Степанов, А.В., Свиридов, Л.П., Ахметели, Г.Г., Коротков, К.Г., Юсубов, Р.Р. Метод этиологической диагностики аллергии путем анализа параметров стимулированного свечения крови // Materials of Internetional Scientific Congress "Science. Information. Spirit.", Russia, St.Petersburg, 4.-5. July, 2009. - p. 52-61.

9. Kostyuk, N., Rajnarayanan, R., Isokpehi, R., Korotkov, K., Howcroft, S., Yeager, M., Mann, H., Cohly, H. Bio-electrographic Method in Detecting Heterogeneity and Unique Features in Autism // Materials of Internetional Scientific Congress "Science. Information. Spirit.", Russia, St.Petersburg, 4.-5. July, 2009.

10. Bell, I., Lewis, D., Brooks, A., Lewis, S., Schwartz, G. Gas Discharge Visualization Evaluation of Ultramolecular Doses of Homeopathic Medicines Under Blinded, Controlled Conditions // Journal of Alternative and Complementary Medicine, 2003, Feb., p. 25-38.

11. Rodina, J. D., Ovcharenko, S.V., Malojvan, J.V. Psychological Aspects of Disabled Sportsmen Training and the Usage of Gas Discharge Visualization Technique // Materials of Internetional Scientific Congress "Science. Information. Spirit.", Russia, St.Petersburg, 4.-5. July, 2009.

12. Velichko, E.N., Sochevanov, V.N., Brunov, V.V. Influence of "Places of Power" of Vologodskaya Area on Human State // Materials of Internetional Scientific Congress "Science. Information. Spirit.", Russia, St.Petersburg, 4.-5. July, 2009.

Anotācija. Rakstā apskatīti jautājumi, kas saistīti ar tekstilmateriālu metāla nanodaļiņu pārklājuma noturību un atbrīvoto daļiņu koncentrācijas noteikšanu üden̄i. Galvenie riski, kas saistīti ar metālpārklātu tekstilmateriālu lietošanu, ir metāla nanodaļiņu atdalī̌̌anās no materiāla lietošanas un kopšanas laikāa. Berzes rezultātā nanodaļiņas var atdalīties no izstrādājuma un tādējādi nonākt gaisā, rezultātā piesārņojot vidi, vai arī ieelpojot noklūu cilvēka vai dzīvnieka organismā. Nanodaļinas var atdalīties no tekstilmateriāla arī mazgāšanas laikā, tādējādi piesārnojot ūdens tilpnes un kaitējot tajās esošajām dzīvajām būtnēm. Š̄ raksta mērksis ir apskatīt iekārtas, kas paredzētas šķidrumos esošo nanodaļiņu izmēru un koncentrācijas noteikšanai. Raksturotas pasaulē pazīstamākās metodes (mikroskopijas metodes, fotonu korelācijas spektroskopija, nanodaļinu trases analizators) un salīdzinātas ar jaunu, alternatīvu metodi - gāzizlādes vizualizācijas (GDV) elektrogrāfiju, kas piemērojama dažādām vajadzībām, bet lìdz šim visbiežāk lietota medicīnsika rakstura pētījumiem. Raksta ietvaros analizètas katras metodes priekšrocības un trūkumi, kā arī novērtētas GDV elektrogrāfijas perspektīvas metāla nanodalıinu noteikšanā ūdenī. 